Int. J. Agril. Res. Innov. Tech. 10(2): 76-83, December 2020 Available online at https://ijarit.webs.com DOI: https://doi.org/10.3329/ijarit.v10i2.51580 https://www.banglajol.info/index.php/IJARIT

\title{
Effects of fodder conservation and ration formulation interventions on dairy performance in Kenya
}

\author{
B.N. Sakwa ${ }^{{ }^{*}}$, J.O. Ondiek ${ }^{1}$, A.M. King'ori ${ }^{1}$ and O.A. Ndambi ${ }^{2}$ \\ Received 8 August 2020, Revised 9 October 2020, Accepted 24 December 2020, Published online 31 December 2020
}

\begin{abstract}
A B S T R A C T
Use of conserved forages and proper ration formulation has great potential to bridge the gap in dairy nutrition and reduce seasonal variations in milk yield. This study determined the effects of various fodder and ration formulation interventions on dairy farm performance in North Rift, Eastern, and Central regions of Kenya. Seventy-two farms were purposively selected as participating farms and assigned into six groups of twelve as follows: two groups on silage production, two groups on ration formulation, and two control groups having similar production systems and in the same geographical locations as the other groups. Data on daily dry matter feed intake and milk yield were recorded while laboratory analysis was done to determine milk butterfat and protein content. The data was analyzed using a multilinear regression model to assess the relationship between independent and dependent variables. The results showed that farmers using feed rationing with advisory services had the highest average daily milk yield $(19.7 \mathrm{~kg} / \mathrm{cow})$ compared to maize train silage (16.8 $\mathrm{kg} / \mathrm{cow}$ ) and those with silage support from Service Provider Enterprises (SPE) (13.3 $\mathrm{kg} /$ cow $)(P<0.05)$. Daily dry matter feed intake/cow varied significantly across the interventions as well as feed utilization efficiency $(P<0.05)$. Milk butterfat and milk protein content did not differ $(P>0.05)$ across the interventions. In conclusion, use of maize train silage and feed rationing with advisory services increased milk yield and reduced seasonal milk fluctuation.
\end{abstract}

Keywords: Feed intake, Maize silage, Milk yield, Silage bales, Service provider enterprises.

${ }^{1}$ Department of Animal Sciences, Egerton University P.O. Box 536-20115, Egerton, Kenya.

${ }^{2}$ Animal Science Group, Wageningen University and Research, Wageningen, Netherlands.

*Corresponding author's email: boniface396@gmail.com (B.N. Sakwa)

Cite this article as: Sakwa, B.N., Ondiek, J.O., King'ori, A.M. and Ndambi, O.A. 2020 Effects of fodder conservation and ration formulation interventions on dairy performance in Kenya. Int. J. Agril. Res. Innov. Tech. 10(2): 76-83. https://doi.org/10.3329/ijarit.v10i2.51580

\section{Introduction}

The dairy sector is the largest agricultural subsector in Kenya, and its share in gross domestic product (GDP) is approximately $4 \%$ (OderoWaitituh, 2017). Dairy farming in Kenya is concentrated in the high altitude Agro-ecological zones of the Eastern, Central highlands and North Rift regions with a high and bimodal rainfall and relatively low temperatures between $15-24^{\circ} \mathrm{C}$. More than three-quarters of the households in the regions engage in agriculture with $73 \%$ practicing integrated crop/dairy production (Wambugu et al., 2011). Dairy feed management and utilization efficiency is the key determinant of dairy farm performance. Conserved forages have great potential to bridge the gap in forage supply and support milk yield during seasonal variations, which will reduce fluctuations in milk supply. The availability of quality forage all year-round is a major challenge of dairy farmers in Kenya leading to low milk yields, low milk solid content and high cost of milk production (Kashangakiand Ericksen, 2018).

Faced with a myriad of constraints, the dairy farmers need to adopt a promising dairy and forage technology especially in utilizing the limited forage resources. This remains critical for increased fodder and milk production and improvement of the performance of dairy industry for economic growth (Mutavi, 2017). This justifies the need to adopt productionenhancing forage innovations and dairy feed rationing as better ways of stimulating milk production to meet the ever-increasing demand for milk.

The SNV Market led Dairy Program (KMDP) in Kenya, funded by the Embassy of the Kingdom of 
Netherlands introduced some interventions on fodder conservation and ration formulation on dairy farms in Kenya, i.e. use of maize train/baled silage and production of silage with support from Service Provider Enterprises (SPEs), and supporting on-farm ration formulation. Maize train and baled silage; - is a concept of silage making that involves a lot of mechanization and commercialization as well as the concept of silage baling to facilitate transportation and proper storage practices. Service provider enterprises maize silage; - Involves groups of entrepreneurial youth trained by the Netherlands development organization (SNV) under the KMDP project. This study therefore, determined the effects of these interventions on dairy farm performance.

\section{Materials and Methods}

\section{Description of study areas}

The study was done in North Rift, Eastern, and Central regions of Kenya. The rainfall in these regions ranged from 900-1300, 1000-2020 and 700-1400 $\mathrm{mm} /$ year, respectively. While the altitude ranged from 1800-2500, 1000-2000, and 1800-2500 meters above sea level, respectively (Jaetzoldet al., 2010).

\section{Data collection and laboratory analysis}

The dairy farms were sampled based on the fodder interventions adopted using the purposive sampling technique. A typology of the farms, which had access to these interventions, was done and the farms classified based on the interventions adopted. A structured questionnaire was used to obtain farm characteristics. Two groups of farms were identified, that is farms producing silage and farms practicing feed rationing. These two groups were further sub-divided as follows:

a) Two groups on silage:

i. Smallholder farms with support from Service Provider Enterprises (SPEs). ii. Medium and large-scale farms using maize train and silage bales.

b) Two groups on feed rationing:

i. Farms practicing ration formulation without regular advisory services and follow-ups.

ii. Farms using the Rumens feed balancing software for ration formulation and with regular farm advisory services.

c) Two control groups representing silage interventions were established comprising of farmers of the same production system in the same geographical location not implementing the interventions and not having access to KMDP farm advisory services.

i. SPE control

ii. Maize train control

Average daily milk yield (kg/cow) was recorded, while laboratory analysis was done per farm for butterfat (Babcock test method), and protein content of the milk (Kjeldahl method) (AOAC, 2012). Average daily feed intake (kg/cow) was determined by weighing feeds offered per day and subtracting feed remaining the following morning before feeding. Feed efficiency was calculated as the ratio of daily milk yield to the daily feed intake per cow.

\section{Statistical analysis}

A multiple-linear regression analysis was used for the relationship between milk yield, butterfat, protein content, feed efficiency, feed intake (DM) and the feeding interventions used. Analysis of variance (PROC GLM) was used to determine differences in feeding interventions and mean separation done using least significant different (LSD) $(P<0.05)$. Data was analyzed using Statistical Analysis Software (SAS, 2008). The model used was:

$\gamma=\beta_{0}+\beta_{1} X_{1}+\beta_{2}\left(X_{1} X_{2}\right)+\beta_{3}\left(X_{1} X_{3}\right)+\beta_{4}\left(X_{1} X_{4}\right)+\beta_{5}\left(X_{1} X_{2} X_{3}\right)+\beta_{6}\left(X_{1} X_{2} X_{4}\right)+\beta_{7}\left(X_{1} X_{3} X_{4}\right)+\beta_{8}\left(X_{1} X_{2} X_{3} X_{4}\right)+\varepsilon$

Where,

$Y=$ is the predicted value of a dependent variable (Daily dry matter intake, Milk yield, milk butter fat, milk protein content, and feed efficiency).

$\beta_{0}=$ the intercept

$\beta_{1}, \beta_{2}, \beta_{3}, \beta_{4}, \beta_{5}, \beta_{6}, \beta_{7}$, and $\beta_{8}=$ regression coefficients

$X_{1}, X_{2}, X_{3}$, and $X_{4}=$ independent variables (interventions, region, farm size and grazing system).

$\mathcal{E}=$ random error term

\section{Results}

The results from the study on milk yield, milk quality, feed intake, and feed efficiency are presented in Table 1, Figure 1 and Figure 2. Milk yield from different interventions differed $(P<0.05)$, where by farms using feed rationing with regular visits and advisory services recorded the highest daily milk yield $(19.7 \mathrm{~kg} / \mathrm{cow})$ compared to farms using maize train/baled silage and those with support from SPEs interventions (16.8 and $13.3 \mathrm{~kg} /$ cow), respectively (Table 1 ). Rationing without visits, maize train/baled and SPEs controls had the lowest daily milk yield per cow compared to their respective farms using the interventions $(P<0.05)$ (Table 1$)$. 
Table 1. Dairy performance under different Interventions.

\begin{tabular}{|c|c|c|c|c|c|c|}
\hline Interventions & $\begin{array}{l}\text { DMFI } \\
(\mathrm{kg})\end{array}$ & $\begin{array}{l}\text { Milk yield per } \\
\text { farm }(\mathrm{kg})\end{array}$ & $\begin{array}{l}\text { Milk yield } \\
\text { per cow }(\mathrm{kg})\end{array}$ & $\begin{array}{l}\text { MP } \\
(\%)\end{array}$ & $\begin{array}{c}\text { MBF } \\
(\%)\end{array}$ & $\mathrm{FE}$ \\
\hline $\begin{array}{l}\text { Maize train silage } \\
(\mathrm{n}=5)\end{array}$ & $16.3 \pm 0.32^{\mathrm{a}}$ & $438.7 \pm 53.49^{\mathrm{ab}}$ & $16.8 \pm 0.53^{b}$ & $2.7 \pm 0.03^{b}$ & $3.6 \pm 0.04^{b}$ & $1.1 \pm 0.03^{\mathrm{a}}$ \\
\hline $\begin{array}{l}\text { Maize train Control } \\
(\mathrm{n}=5)\end{array}$ & $14.4 \pm 0.1$ & $220.2 \pm 50.96^{b c}$ & $14.2 \pm 0.27^{\mathrm{cd}}$ & $2.6 \pm 0.02^{c}$ & $3.7 \pm 0.04^{\mathrm{a}}$ & $0.9 \pm 0.04^{b}$ \\
\hline $\begin{array}{l}\text { Rationing and } \\
\text { advisory services } \\
(\mathrm{n}=5)\end{array}$ & $17.3 \pm 0.34^{\mathrm{a}}$ & $630.4 \pm 181.92^{\mathrm{a}}$ & $19.7 \pm 0.64^{a}$ & $2.8 \pm 0.02^{\mathrm{a}}$ & $3.6 \pm 0$ & $1.1 \pm 0.05^{\mathrm{a}}$ \\
\hline $\begin{array}{l}\text { Rationing without } \\
\text { visits }(n=5)\end{array}$ & $14.9 \pm 0.42^{b}$ & $467.8 \pm 132.82^{\mathrm{ab}}$ & $15.1 \pm 0.61^{b c}$ & $2.7 \pm 0.02^{b}$ & $3.7 \pm 0.02^{\mathrm{a}}$ & $1.0 \pm 0.03^{b}$ \\
\hline SPEs silage $(n=5)$ & $13 \cdot 7 \pm 0.45^{c}$ & $113.8 \pm 39.23^{c}$ & $13 \cdot 3 \pm 0.88^{\mathrm{d}}$ & $2.6 \pm 0.02^{c}$ & $3.7 \pm 0.04^{\mathrm{a}}$ & $0.9 \pm 0.08^{b}$ \\
\hline SPEs Control $(n=5)$ & $13.2 \pm 0.73^{c}$ & $23.1 \pm 4.05^{c}$ & $10.4 \pm 0.47^{\mathrm{e}}$ & $2.6 \pm 0.03^{c}$ & $3.7 \pm 0.04^{\mathrm{a}}$ & $0.8 \pm 0.04^{c}$ \\
\hline Pvalue & $<0.0001$ & 0.0014 & $<0.0001$ & 0.1336 & $<0.0001$ & 0.0010 \\
\hline$R^{2}$ & 0.72 & 0.54 & 0.85 & 0.28 & 0.70 & 0.55 \\
\hline
\end{tabular}

$D M F I=$ Dry matter feed intake, $F E=$ Feed efficiency, $M B F=$ Milk butterfat, $M P=$ Milk protein, SPEs= Service provider enterprises, abcMeans within columns with different superscripts differ significantly at $P<0.05$.

Medium/large scale farms practicing feed rationing with advisory services and regular visits performed better than farms using maize train/baled silage interventions $(P<0.05)$. While their medium/large scale control farms' (maize train control and farms practicing feed rationing without advisory services and regular visits) performance did not vary significantly.

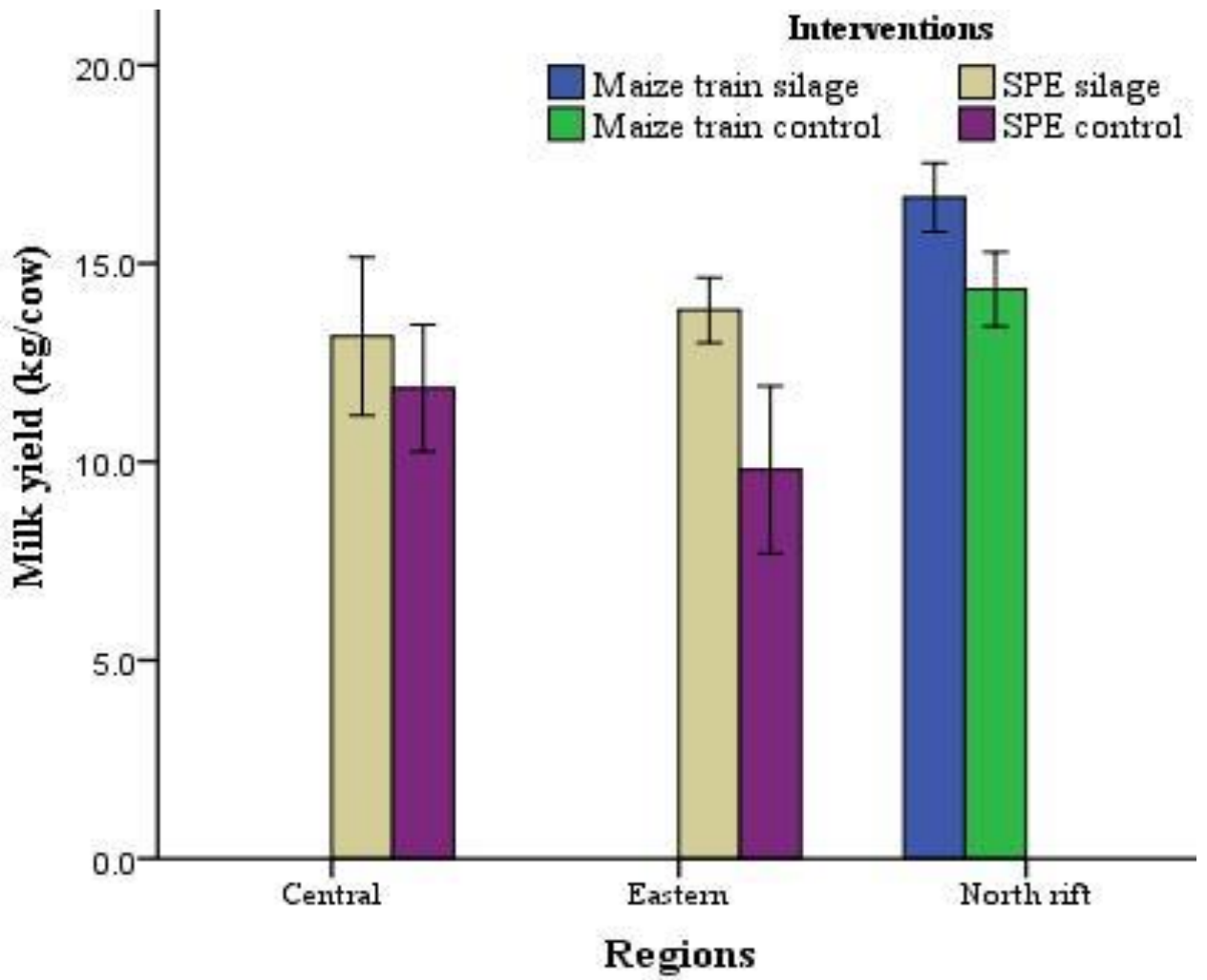

Fig. 1. Comparison of fodder conservation interventions in different regions of Kenya.

However, farms in Central and Eastern regions of Kenya practicing feed rationing with advisory services and regular visits had higher daily milk yield (19.1 and $18.6 \mathrm{~kg} / \mathrm{cow})$, respectively,
Farms using maize train silage interventions in North Rift region of Kenya had higher average daily milk yield ( $16.7 \mathrm{~kg} / \mathrm{cow}$ ) compared to those with support from service provider enterprises (SPE) intervention in both Eastern and Central regions of Kenya (13.8 and $13.2 \mathrm{~kg} / \mathrm{cow}$ ), respectively (Fig. 1).

\section{Interventions}

Maize train control $\square$ SPE control

compared to those practicing fodder conservations using maize train intervention in North Rift (Fig. 2). 


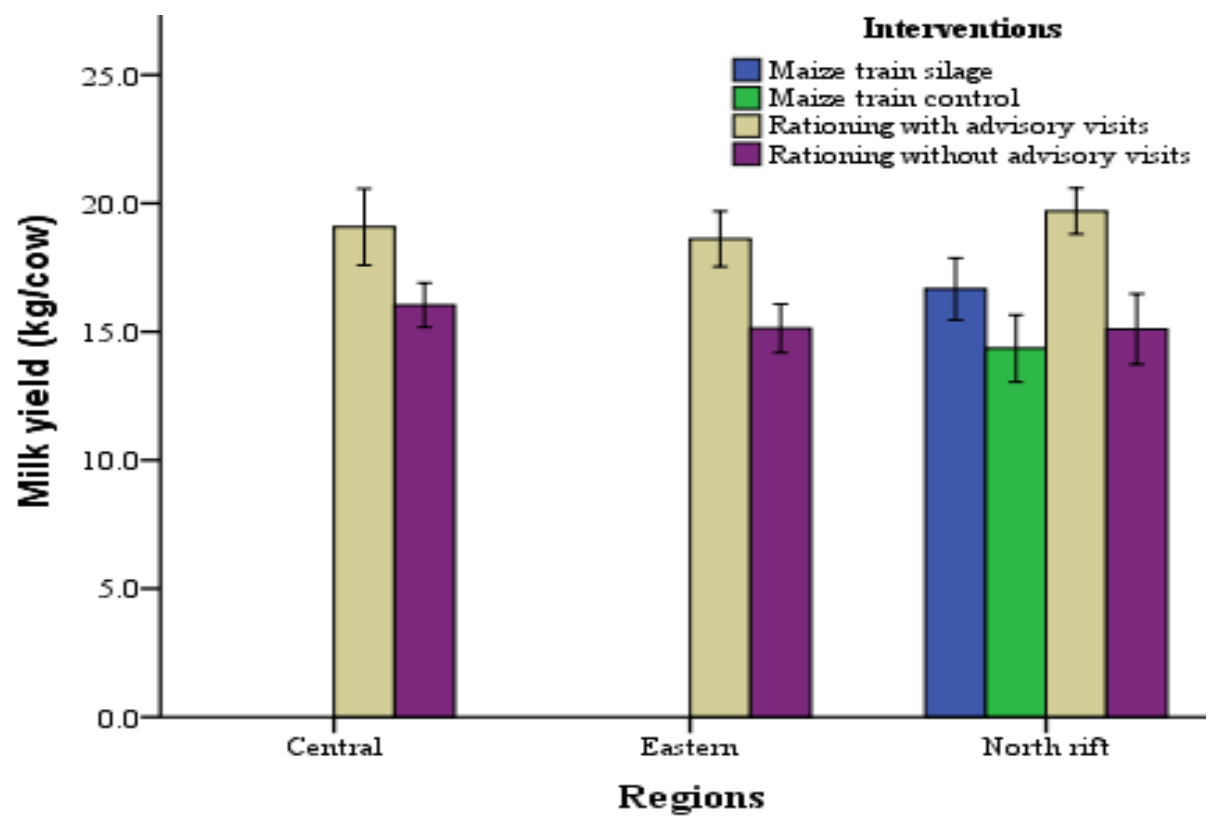

Fig. 2. Comparison of rationing and fodder interventions in different regions of Kenya.

Milk butterfat and milk protein contents differed $(P<0.05)$ across the interventions. Medium/large-scale farms not using the interventions and the smallholder farms under SPE had higher milk butter fat content (3.7\%) than those medium/large-scale farms using maize train and feed rationing with advisory services interventions (3.6\%) (Table 1). Milk protein content was higher in medium/largescale farms practicing feed rationing with advisory services (2.8\%) and lowest in smallholder farms using support from SPE and the medium/large-scale maize train control farms (Table 1).

Average daily dry matter feed intake (DMFI $\mathrm{kg} / \mathrm{cow}$ ) varied significantly across the interventions. Medium/large-scale farms practicing feed rationing with advisory services and those using maize train silage interventions had the highest average DMFI per cow was 17.3 $\mathrm{kg}$ and $16.3 \mathrm{~kg}$, respectively. Medium/large-scale farms under maize train control and feed rationing without advisory services, and the smallholder farms with support from SPEs had the lowest daily DMFI per cow was $14.4 \mathrm{~kg}, 14.9$ $\mathrm{kg}$, and $13.7 \mathrm{~kg}$, respectively (Table 1 ).
Feed efficiency which measures the effectiveness of a diet on milk yield, varied significantly $(P<0.05)$ across the interventions. Medium/large farms practicing feed rationing with advisory services and those using maize train interventions had an average feed efficiency of 1.1 higher than 0.8 from smallholder SPE control farms (Table 1).

The results from the regression models used are presented in Table 2 below for the derived optimal models on the basis of smallest AIC, BIC, $\mathrm{C}(\mathrm{p})$ and SSE values and largest $\mathrm{R}^{2}$. About $70 \%$ of the variations in daily milk yield/cow was explained by the interventions and grazing systems. Only 30\% variability in daily milk yield/cow was due to variations in region and farm size. Similarly, $66 \%$ of the variability in feed intake per cow per day (kg DM) was explained by the different intervention levels and grazing systems. In contrast, variability in milk butter fat (26\%), milk protein (0.7\%) and feed efficiency (45\%) was due to different interventions, grazing systems, farm sizes and grazing systems, respectively (Table 2 ).

Table 2. Optimal models selected for explaining dependent variables.

\begin{tabular}{|l|l|l|l|l|l|l|l|}
\hline $\begin{array}{l}\text { Model } \\
\text { Daily milk } \\
\text { yield/cow }\end{array}$ & Interventions, grazing system & 0.7 & 27.3 & 31.1 & 1.7 & 59.4 & 0.004 \\
$\begin{array}{l}\text { Daily dry matter } \\
\text { feed intake/cow }\end{array}$ & Interventions, grazing system & 0.7 & 22.8 & 25.9 & 2.9 & 45.7 & 0.007 \\
\hline $\begin{array}{l}\text { Milk butter fat } \\
\text { content }\end{array}$ & Interventions & 0.3 & -63.2 & -60.6 & 1.8 & 0.3 & 0.425 \\
\hline $\begin{array}{l}\text { Milk protein } \\
\text { content }\end{array}$ & Interventions, grazing system & 0.1 & -95.8 & -92.6 & -0.4 & 0.1 & 0.912 \\
\hline \begin{tabular}{l} 
Feed efficiency \\
\hline
\end{tabular} & Intervention, grazing system & 0.5 & -78.1 & -74.3 & 1.2 & 0.1 & 0.102 \\
\hline
\end{tabular}


The optimal models derived for estimating the dependent variables were:

Milk yield $=25.97-0.63 \mathrm{R}-1.77 \mathrm{Int}+0.69 \mathrm{FS}-2.95 \mathrm{GS}$

Dry matter feed intake $=24.5 \mathrm{O}-0.69 \mathrm{R}-1.28 \mathrm{Int}-0.55 \mathrm{FS}-2.40 \mathrm{GS}$

Milk butter fat $=3.45+0.08 \mathrm{R}+0.03 \mathrm{Int}-0.06 \mathrm{FS}-0.09 \mathrm{GS}$

Milk protein content $=2.68-0.002 \mathrm{R}+0.01 \mathrm{Int}+0.02 \mathrm{FG}-0.02 \mathrm{GS}$

Feed efficiency $=0.89+0.01 \mathrm{R}-0.01 \mathrm{Int}+0.11 \mathrm{FG}-0.07 \mathrm{GS}$

Where,

$\mathrm{R}=$ Regions (North Rift, Central and Eastern)

Int = Interventions (FRASV=Feed rationing with advisory services and regular follow-ups, Maize train/baled silage, Service provider enterprises (SPEs) silage)

FS $=$ Farm sizes (Large and Medium scale)

$\mathrm{GS}=$ Grazing systems (Zero grazing and Semi-zero grazing system) .

$R^{2}=$ coefficient of determination, $A I C=$ Akaike information criterion, $B I C=$ Bayesian information criteria, $C(p)=$ Cp statistic metric, and $S S E=$ residual sum of squares. (Metrics used for comparing regression models quality and selection, measuring the performance of regression model. The higher the $R^{2}$ the better the model, while the lower the $A I C, B I C$ gives the optimal model).

\section{Discussion}

This study gave an insight into the impact of fodder conservation and ration formulation interventions on daily dry matter feed intake, milk yield, milk butterfat, milk protein, and feed efficiency among dairy farms in Kenya. The genetic potential of a cow is achieved only when the diet fed meets the nutritional requirements commensurate with the genetic potential. Therefore, a well-formulated feed ration and quality conserved fodder is required for increased productivity (FAO, 2012; Garg et al., 2013). However, cows kept in most of the dairy farms in Kenya are rarely fed based on their nutritional requirement (Garg et al., 2013). This is confirmed by this study among the farms not using the interventions.

When all the animal factors (breed, stage of lactation, and body weight) were kept constant, dairy cows on rations from feed balancing with advisory services and regular follow-ups had better performance compared to the other interventions and their controls. The variations in milk yield within the interventions may be explained by variations in feed quality and quantity being used. The feed balancing with advisory services and regular follow-ups enabled dairy ration formulation by considering the animal's nutrient requirements for production. An increase in metabolizable energy and crude protein intake leads to an increase in milk yield (Johnson et al., 2016). Significant high daily milk yield was observed among the farms practicing feed rationing with advisory services and regular visits. This demonstrated that the cows responded well to well-balanced rations. This is in line with findings by FAO, (2012) where a ration balancing was introduced. Research carried out by Kannan et al. (2011); Sherasia et al. (2016); Deen et al. (2019) showed a positive effect of balanced rations on daily milk yield. This shows that feed rationing with advisory services and regular visits can be an effective way to increase dairy performance among dairy farms in Kenya.

During the adoption of these interventions by most dairy farms, general advisory services and regular follow-ups were given to improve farm management. Examples of the advices were on forage production, conservation and storage, housing, re-grouping of cows based on their production potential, calf rearing, etc. (Ettema, 2015). These general improvements in management probably led to better animal health and welfare and thereby an increase in dairy performance (Moran, 2009). Therefore, in addition to a well-balanced feed rations, changes in farm management were likely contributors to the observed increase in dairy productivity among the farms practicing feed balancing with advisory services.

Farms, which were not using any of the interventions (control farms) had lower milk yield, which was attributed to the feeding rations that did not meet the production potential of the dairy cows. This was due to feeding of low-quality feed resources, predominantly Napier grass, natural pastures, and crop residues that are low in metabolizable energy and crude protein. Kashongwe et al. (2017) reported that Napier grass and other natural pastures are low in dry matter content (20-35\%), crude protein (8-10\%) and contain high crude fibre of over $37 \%$, which makes them insufficient to support high milk production.

The low milk yield observed in smallholder SPEs farms was due to low quality and quantity of feeds. Most farms relied on Napier grass and little silage for their dairy cows. The cows were often fed concentrates, either dairy meal or other industrial by-products (maize germ, wheat bran, wheat pollard) most often in low amounts of less than $2 \mathrm{~kg} \mathrm{DM} /$ day. Feeding in these farms was not adjusted based on the production potential of cows. Similar observations are reported by Richards et al. (2015, 2016). The low rates of 
energy and protein supplied resulted to undernutrition in the early part of the lactation cycle and affected milk production throughout the lactation, a similar observation was reported by Moghaddam (2016). Jansen et al. (2019) reported increases in daily milk production and better animal health, linking the change to the SPE services. Farms from Meru County in Eastern region, where SPEs made the most silage, reported daily milk increases from between 5.0-6.0 to between 8.0-9.5 litres per cow. This was lower than 13.8 litres per cow increase reported in this study in Eastern region. This was due to more improved and availability of conserved maize silage in the region.

Farms using maize train silage had better daily milk yield/cow compared to SPE silage farms. This can be attributed to the good quality of maize train silage in terms of metabolizable energy (11.9 MJ/kg DM), dry matter (>30\%) and organic matter digestibility (56.4\%) compared to SPE silage which had metabolizable energy of 9.2 $\mathrm{MJ} / \mathrm{kg} \mathrm{DM},<30 \%$ dry matter content, and organic matter digestibility of 50.9\%. Most of the SPE farmers in Central and Eastern regions lacked sufficient land for forage production, majority of who own between 0.5 to 5.0 acres out of which $80 \%$ is committed to food crop production (Kashangaki and Ericksen, 2018). This contributed to high milk yield in North Rift region under the interventions and low yield in Central and Eastern regions. Similar findings were reported by Kilelu et al. $(2017,2018)$ in a study done in Central, Eastern and Rift Valley regions of Kenya. Farms under maize train silage and those practicing feed rationing with advisory services in North Rift Kenya performed better due to the sustainable intensification of feeding systems with efficient use of fodder and concentrate feed, so that the proportion of the intake from feeds remained high, and the efficiency of use of concentrate ( $\mathrm{kg}$ milk/ $\mathrm{kg}$ concentrate) was also high compared to their controls which was attributed to feeding systems with low input grazing strategy adopted. Similar observations were reported by Llanos et al. (2018).

Medium/large-scale farms in Central and Eastern regions invested more in commercial concentrates to supplement their dairy cows with the required metabolizable energy and protein for milk production. This was possible due to close proximity of readily available market for milk-as the urban centres are very near, hence need for high energy and protein feeds for their dairy cows. However, the quantity of concentrates used in smallholder farms using support from SPE silage was low ( $<2 \mathrm{~kg} / \mathrm{cow} /$ day) which was not commensurate with amount of milk produced due to unavailability of quality feeds throughout the year. Similar observations were reported by Muia et al. (2011).
Lukuyu et al. (2011) attributed low milk yield to poor nutrition and lack of supplementation with high proteins. The results from small-scale dairy farms using SPEs silage concurs with reports by Kilelu et al. $(2017,2018)$ who noted that farms using support from SPEs intervention performed better than the controls. However, comparing with farms using maize train silage in North Rift region, SPEs had low performances, which is attributed to in adequate and low-quality feed resources.

The low milk yield of $10.4 \mathrm{~kg} / \mathrm{cow} /$ day observed in the farms without support from SPE intervention was comparable to the results by Muia et al. (2011) who reported milk production of $8.4 \mathrm{~kg} / \mathrm{cow} /$ day in the Central regions while Mungube et al. (2014) reported milk yield of $6 \mathrm{~kg} / \mathrm{cow} /$ day in the semi-arid region of Eastern Kenya. This shows that dairy interventions had a significant improvement on dairy cow performance. Feeding higher amounts of concentrate in early-mid lactation stages is reported to increase milk yield by $20 \%$ (Purcell et al., 2016). This finding was observed in medium/large-scale farms using feed rationing with advisory services, where large amounts of concentrates was being used to supply enough nutrients for milk synthesis.

High daily feed intake was attributed to quality feed rations, made of quality maize silage and concentrates formulated with advisory services and regular follow-ups by the feed nutritionists from the Kenya market-led dairy program (KMDP), this concurs with reports by Ferguson, (2017) and Ayuya et al. (2018) who noted that dairy feed ration balanced with all nutrients particularly for protein and calcium is essential for both rumen digestion of feedstuffs and milk production. This also suggests that cows in control farms lacked a balanced supply of nutrients in the feeds and feed rations provided, which led to low dry matter feed intake as well as milk production. Explanations can be lack of nutritional knowledge, costs of diet ingredients or availability of feed resources. With the increase in human population, increasing acreage for forage production to meet nutritional requirements is not the solution (FAO, 2018). Sustainable production intensification is required to meet fodder productivity potential (Jayne et al., 2014). Therefore, high quality forage should be produced and conserved (Ettema, 2015; Lukuyu et al., 2011).

This study shows a significant effect of quality feed rations on milk yield as observed among farms using the feed balancing software. Maize train silage intervention farms had better feed intake compared to farms using silage from SPEs that was attributed to the quality of silage used based on the right stage of harvesting and proper ensiling process that increases organic matter digestibility, dry matter intake, and energy 
content. Lawrence, (2019) noted that highest dry matter intake of conserved maize silage in dairy cows occurs when maize is harvested at physiological maturity stage with (32 to $40 \%$ DM).

Low milk butterfat recorded in farms with feed balancing software was attributed to the type of rations used, which was high in concentrate to forage ratio. Farms using SPEs silage intervention had high milk butter fat content attributed to the high proportion of forages used compared to concentrates. Roughages are associated with higher acetate production, hence higher milk butter fat content (Kashongwe et al., 2014).

\section{Conclusion}

The study revealed that use of maize train/baled silage and feed rationing with advisory services and regular follow-ups are ideal and sustainable interventions for increased milk yield in medium/large-scale farms. Similarly, use of SPE silage by smallholder farms in Central and Eastern regions of Kenya increased milk production leading to increased farm incomes and growth in sustainable and competitive farming enterprises.

\section{Acknowledgements}

The authors wish to thank the $3 \mathrm{R}$ (Robust, Reliable, and Resilient) - from 'Aid to Trade' project, funded by the Embassy of the Kingdom of Netherlands in Kenya for supporting this research work. Much gratitude also goes to the dairy farmers who participated in this project.

\section{Conflicts of Interest}

The authors declare no conflict of interest.

\section{References}

AOAC. 2012. Official Methods of Analysis. 19 ${ }^{\text {th }}$ Edition, Association of Official Analytical Chemists. Washington, DC, USA. pp. 12-56.

Ayuya, I.O., Beekman, G. and Koster, T. 2018. Potential impact of strategies by dairy entrepreneurs to tackle fodder shortages. Research report 007. Wageningen University and Research, Wageningen, The Netherland. $\quad$ pp. 20-25. https://bit.ly/2Tf8RPZ. Accessed on 12 March 2020.

Deen, A.U., Tyagi, N., Yadav, R.D., Kumar, S., Tyagi, A.K. and Singh, S.K. 2019. Feeding balanced ration can improve the productivity and economics of milk production in dairy cattle: a comprehensive field study. Trop. Animal Health Prod. 51: 737-744.

https://doi.org/10.1007/s11250-018-1747-8

Ettema, F. 2015. SNV/KMDP Status Report Medium-scale farmers and commercial fodder producer's agenda (including PUM Evaluation 2015). Leeuwarden. pp. 19-21.

FAO. 2012. Balanced feeding for improving livestock productivity-Increase in milk production and nutrient use efficiency and decrease in methane emission. In: FAO Animal Production and Health Paper. Rome, Italy. pp. 31-42.

FAO. 2018. Livestock production systems spotlight: Cattle and poultry sectors in Kenya. pp. 46-49. Retrieved from http://www.fao.org/ag/againfo/programme s/en/ASL2050.html

Ferguson, J.D. 2017. Nutritional strategies to improve nitrogen efficiency and milk protein synthesis in dairy cow. Achieving sustainable production of milk. Vol. 1, BurleighDodds Science Publishing. Cambridge, UK. pp. 283-332.

https://doi.org/10.19103/AS.2016.0005.11

Garg, M.R., Sherasia, P.L., Bhanderi, B.M., Phondba, B.T., Shelke, S.K. and Makkar, H.P.S. 2013. Effects of feeding nutritionally balanced rations on animal productivity, feed conversion efficiency, feed nitrogen use efficiency, rumen microbial protein supply, parasitic load, immunity and enteric methane emissions of milking animals under field conditions. Animal Feed Sci. Tech. 179(1-4): 24-35.

https://doi.org/10.1016/j.anifeedsci.2012.11.005

Jaetzold, R., Schmidt, H., Hornetz, B. and Shisanya, C. 2010. Farm management handbook of Kenya. Vol. II. Natural conditions and farm management information. $2^{\text {nd }}$ Edition, Part B. Central Kenya-Southern Rift valley Province. pp. 1821.

Jansen, A., Kilelu, C., David, M. and van der Lee, J. 2019. Youth-led providers enterprise Kenya. SNV's Kenya Market-led Dairy Programme (KMDP), the $3 \mathrm{R}$ Kenya project, Wageningen University and Research, Wageningen. Netherlands. pp. 36-38. https://www.cta.int. Accessed on $25^{\text {th }}$ January 2020.

Jayne, T.S., Chamberlin, J. and Headey, D.D. 2014. Land pressures, the evolution of farming systems, and development strategies in Africa: A synthesis. Food Policy. 48: 1-17.

https://doi.org/10.1016/j.foodpol.2014.05.014

Johnson, I.R., France, J. and Cullen, B.R. 2016. A model of milk production in lactating dairy cows in relation to energy and nitrogen dynamics. J. Dairy Sci. 99(2): 1605-1618. https://doi.org/10.3168/jds.2015-10068

Kannan, A., Garg, M.R. and Kumar, B.V.M. 2011. Effect of ration balancing on milk production, microbial protein synthesis and methane emission in crossbred cows under field conditions in Chittoor district of Andhra Pradesh. Indian J. Animal Nutri. 28: 117-132. 
Kashangaki, J. and Ericksen, P.J. 2018. Costbenefit analysis of fodder production as a low emissions development strategy for the Kenyan dairy sector. ILRI Project Report. pp. 14-15.

Kashongwe, O.B., Bebe, B.O., Matofari, J.W. and Huelsebusch, C.G. 2017. Effects of feeding practices on milk yield and composition in peri-urban and rural smallholder dairy cow and pastoral camel herds in Kenya. Trop. Animal Health Prod.49: 909-914. https://doi.org/10.1007/s11250-017-1270-3

Kashongwe, O.B., Migwi, P., Bebe, B.O., Ooro, P.A., Onyango, T.A. and Osoo, J.O. 2014. Improving the nutritive value of wheat straw with urea and yeast culture for dry season feeding of dairy cows. Trop. Animal Health Prod. 46: 1009-1014. https://doi.org/10.1007/s11250-014-0598-1

Kilelu, C.W., Koge, J. and van der Lee, J. 2017. Performance of dairy service agrienterprises: A case study of youth-led Service Provider Enterprises (SPE). 3R Kenya Project Practice brief 002. Wageningen Livestock Research, Wageningen, Netherlands. pp. 19-23. https://bit.ly/2utA88Z. Accessed on 10 February 2020.

Kilelu, C.W., Koge, J., Kabuga, C. and van der Lee, J. 2018. Performance of emerging dairy services agri-enterprises: a case study of youth-led service provider enterprises (SPE). (Wageningen Livestock Research report; No. 1094), (3R Research report; No. o01). Wageningen Livestock Research, Wageningen, The Netherland.

https://doi.org/10.18174/446466

Lawrence, J. 2019. Dynamic harvest and storage for improved forage utilization. pp. 17-21. https://hdl.handle.net/1813/60850. Accessed on 02 January 2020.

Llanos, E., Astigarraga, L. and Picasso, V. 2018. Energy and economic efficiency in grazing dairy systems under alternative intensification strategies. European $J$. Agron. 92: 133-140.

https://doi.org/10.1016/j.eja.2017.10.010

Lukuyu, B., Franzel, S., Ongadi, P.M. and Duncan, A.J. 2011. Livestock feed resources: Current production and management practices in central and northern Rift valley provinces of Kenya. Livestock Res. Rural Dev. 23(5): 112.

Moghaddam, G.A. 2016. The relationships between milk production and some blood metabolites and their effects on returning to estrus in lactating Holstein dairy cows. Iranian J. Ruminants Health Res. 1(2): 35-45.

Moran, J.B. 2009.Key performance indicators to diagnose poor farm performance and profitability of smallholder dairy farmers in Asia. Asian-Australasian J. Anim. Sci. 22(12): 1707-1717.

https://doi.org/10.5713/ajas.2009.90201
Muia, J.M.K., Kariuki, J.N., Mbugua, P.N., Gachuiri, C.K., Lukibisi, L.B., Ayako, W.O. and Ngunjiri, W.V. 2011.Smallholder dairy production in high altitude Nyandarua milkshed in Kenya: Status, challenges and opportunities. Livestock Res. Rural Dev. 25(4): 127.

Mungube, E.O., Njarui, D.M.G., Gatheru, M., Kabirizi, J. and Ndikumana, J. 2014. Reproductive and health constraints of dairy cattle in the peri-urban areas of semi-arid eastern Kenya. Livestock Res. Rural Dev. 26(98): 57-60.

Mutavi, S.K. 2017. Determinants of adoption of forage technologies among peri-urban dairy farmers in the semi-arid region of South Eastern Kenya. Doctoral Dissertation. Department of Agricultural Management, South Eastern Kenya University. pp. 87-89. http://repository.seku.ac.ke/handle123456789 /3364. Accessed on 20 January 2020.

Odero-Waitituh, J.A. 2017. Smallholder dairy production in Kenya: a review. Livestock Res. Rural Dev. 29(7): 139.

Purcell, P.J., Law, R.A., Gordon, A.W., McGettrick, S.A. and Ferris, C.P. 2016. Effect of concentrate feeding method on the performance of dairy cows in early to midlactation.J. Dairy Sci. 99(4): 2811-2824. https://doi.org/10.3168/jds.2015-9988

Richards, S., VanLeeuwen, J.A., Shepelo, G., Gitau, G.K., Collins, C.K., Uehlinger, F. and Wichte, J. 2015. Association of farm management practices with annual milk sales in smallholder dairy farms in Kenya. Vet. World. 8(1): 88-96.

https://doi.org/10.14202/vetworld.2015.88-96

Richards, S., VanLeeuwen, J.A., Shepelo, G., Gitau, G.K., Wichte, J., Kamunde, C. and Uehlinger, F. 2016. Randomized controlled trial on impacts of dairy meal feeding interventions on early lactation milk production in smallholder dairy farms of Central Kenya. Prev. Vet. Med. 125: 46-53. https://doi.org/10.1016/j.prevetmed.2016.01.006

SAS (Statistical Analysis System). 2008. SAS for windows, Release 9.2. User's Guide. SAS Institute, Inc., Cary, NC, USA. Accessed on 15 February 2020.

Sherasia, P.L., Phondba, B.T., Hossain, S.A., Patel, B.P. and Garg, M.R. 2016.Impact of feeding balanced rations on milk production, methane emission, metabolites and feed conversion efficiency in lactating cows. Indian J. Anim. Res. 50(4): 505-511. https://doi.org/10.18805/ijar.8595

Wambugu, S., Kirimi, L. and Opiyo, J. 2011. Productivity trends and performance of dairy farming in Kenya. AWPS 43/2011. Tegemeo Institute of Agricultural Policy (No. 680-2016-46762). pp. 487-494. 